\title{
THE CULPABILITY OF ACCOUNTING PRACTICE IN PROMOTING BRIBERY AND CORRUPTION IN DEVELOPING COUNTRIES
}

\author{
by
}

\author{
Olatunde Julius Otusanya \\ Department of Accounting \\ Faculty of Business Administration \\ University of Lagos \\ Sarah Lauwo \\ Department of Accounting \\ Essex Business School \\ University of Essex \\ $\&$ \\ Amal Hayati Ahmad Khair \\ Department of Accounting and Finance \\ Hull University Business School \\ University of Hull
}

\author{
Correspondence Address \\ Department of Accounting \\ Faculty of Business Administration \\ University of Lagos \\ P.O.Box 354 Unilag, Akoka, Yaba, \\ Lagos State, Nigeria \\ E-mail: jotusanya@unilag.edu.ng or sanyaoj@yahoo.co.uk \\ Tel: 234 (0) 7051827072 or (0) 18792949
}




\title{
THE CULPABILITY OF ACCOUNTING PRACTICE IN PROMOTING BRIBERY AND CORRUPTION IN DEVELOPING COUNTRIES
}

\begin{abstract}
Bribery and corruption are increasing in the developing countries. It has been estimated that some $\$ 400$ billion of bribe is paid to political elite in developing countries. Such huge amounts of money cannot be successfully executed without the active involvement of multinational companies (MNCs) from the Western countries. This paper examines the processes involved in the misapplication of accounting practice from the perspective of anti-social criminal practices. It analyses the implication of accounting practice in the construction of MNCs bribery and corruption activities. The paper locate MNCs enterprise culture and accounting practice within the broader dynamics of global capitalism to argue that the drive for higher profit at almost any cost is not constrained by accounting rules, laws and even periodic regulatory actions. The paper uses publicly available evidence to illuminate the role of accounting technology in concealing and facilitates MNCs corrupt practices in developing countries. Evidence is provided to show that to secure and retain business in developing countries and to gain competitive advantages MNCs have engaged in bribery and corruption. The paper also makes suggestions for reform.
\end{abstract}

Keywords: Accounting, Bribery, Corruption, Multinational Companies, Developing countries, transparency, Accountability 


\title{
THE CULPABILITY OF ACCOUNTING PRACTICE IN PROMOTING BRIBERY AND CORRUPTION IN DEVELOPING COUNTRIES
}

\begin{abstract}
1. Introduction
Corruption is a recurring feature in media coverage. It comprises a wide range of activities, such as bribery, money-laundering, fraud, embezzlement, abuse of power, white-collar crime, identity theft, conflict of interest and many more practices (see Otusanya, 2010). In common with many other socially constructed practices corruption may be difficult to define precisely, but its effects are all too visible (Sikka, 2008). In general, bribery and corruption involve attempts to gain unfair advantage (Shazson, 2007). Corruption undermines the rule of law, stifles economic growth, and denies many their rightful share of economic resources. Corruption is therefore a major obstacle to economic and social development (Otusanya, 2011a). A comprehensive analysis of such matters is beyond the scope of this paper. Instead, it explores some aspects of the supply side of corruption in a developing country and the implication of accounting.
\end{abstract}

The prevalence of corruption in developing countries has attracted a great deal of attention in the literature. Most existing studies focus on the demand side of the corruption, that is, on the corrupt official who receive bribes (see Rose-Ackerman, 1978; Gillespie and Okruhlik, 1991; Zakiuddin and Haque, 2002; Olurode, 2005; AAPPG, 2006), a number of other scholars and reports have argued that bribe money often stems from MNCs based in the world's richest countries (Briloff, 1981; AAPPG, 2006; Christian Aid, 2006; Transparent International, 2009; Sikka, 2008; Otusanya, 2010; 2011c). There has been an explosion of media headings reporting investigations, prosecutions and settlements of bribery and corruption violations involving MNCs and their executives, directors and employees (Briloff, 1981; Vanasco, 1999). Thus developing countries cannot therefore be accused of being corrupt without the connection of corrupters - 'supply side' (Varese, 2000, AAPPG, 2006; Annual Integrity Report, 2005-2006; Sikka, 2008; Otusanya, 2010, 2011a). Therefore, corruption is not a marginal issue but central concern for business - in developing, emerging and industrialised countries alike (Transparency International, 2009).

Accounting calculus and ideologies have become a major influence on commercial and everyday life (Mitchell et al., 1998; Neu et al., 2010). Based on a body of rules or national and international standards, accounting is built on a formalistic framework whose aim should be to provide relevant, unbiased information (Compin, 2008). It has been argued that accounting has developed as a means of recording transactions and identifying, and thereby inhibiting, fraudulent activity (Mitchell et al., 1998; Compin, 2008). The expansion of MNCs activities has been aided by accounting technologies that emphasise private property rights and appropriation of economic surpluses (Johnson 1972; Briloff, 1981; Tinker, 1985). 
Accounting technologies lubricate the wheels of capitalism through a variety of schemes to enable capital to advance its interests. Although corporations are created through law and numerous social contracts, in their search for higher profits and financial gains, MNCs do not owe allegiance to any one particular nation, community or locality (Bakan, 2004). The mobility of MNCs is shaped by changes in contemporary capitalism where corporate performance and values are driven by higher earnings. Under pressure to compete with other companies and to increase profits, capitalist enterprises, including MNCs, constantly search for new ways of increasing their profits, and one way in which they do so is by developing complex financial structures in order to conceal their bribe payment and corrupt practices (Briloff, 1981; Compin, 2008). Auditing and internal control systems seek to foster trust and encourage the belief that companies are transparent and their directors are accountable (Sikka, 2008). Yet, accounting provides sophisticated support to the criminal approach and serves as a risk minimisation tool (Briloff, 1981; Tinker, 1985; Compin, 2008).

A number of studies have examined the role of accounting and accountants in relation to the social, economic and political involvement of MNCs in anti-social financial practices (Briloff, 1976, 1981; Tinker, 1985; Mitchell et al., 1998; Sikka, 2008; Owolabi, 2011). Studies examining the role of accountancy firms and professionals in money laundering (Mitchell et al., 1998; Sikka, 2008; Otusanya, 2012), bribery and corruption (Sikka, 2008; Bakre, 2008; Otusanya, 2010; 2011b), the way accounting is used in money laundering and money dirtying (Compin, 2008) allude to and indirectly illustrate the use of accounting practice within organisations. But comparatively little research has addressed the use of accounting practice in anti-social and predatory acts of MNCs and their affiliates in developing countries (Otusanya, 2010; 2011abd).

Accounting is expected to expose financial irregularities in company accounts by enhancing transparency and accountability and by developing techniques for fraud detection. However, an emerging body of literature argues that accounting have increasingly been used to conceal and promote anti-social practices (Briloff, 1976, 1981; Tinker, 1985; Sikka, 2008; US Senate Permanent Sub-Committee on Investigations, 2005; Bakre 2007, 2011). Positioning accounting as a determinant element of financial criminal practices presupposes an epistemological examination of accounting knowledge. As well as being a technique, accountancy can also be a language, an act and a science (Compin, 2008). Compin (2008) further argued that 'no matter how it is qualified, accounting knowledge can be used to aid and abet financial crime. As a technique, accountancy adds a sophisticated edged to criminal operations' (p. 592).

In this paper we adopt such an alternative standpoint, to illuminating the role accounting played in cases of bribery and corruption by MNCs. This is because corruption thrives when accountability and transparency are absent (Johnson, 2005). The paper provides evidence to show the involvement of multinational companies through the use of accounting to facilitate their bribery and corrupt practices which are carried out in order to gain competitive advantages, increased profits and high return to capital but which cause harm to individuals (see Briloff, 1976, 1981; Tinker, 1985; Otusanya, 2010). Such 'darker' practices are located within the broader dynamics of global capitalism where 
corporations use a variety of schemes to gain competitive advantages and to increase profits.

The paper contains five further sections. Section 2 adopts the theoretical framework of global capitalism and the role of accounting in order to help understand how a corporate drive for increased profits and competitive advantage may persuade MNCs to engage in anti-social practices. Section 3 examines the existing literature on corrupt practices and the various cases that have been used to explore the phenomenon of corrupt practices by MNCs in developing countries. Section 4 reviews the anti-corruption regime in the US and the need for efficient and adequate internal control systems to prevent illegal act such as bribery of foreign officials and government to secure or maintain contract overseas. Section 5 provides evidence to show that, despite laws, regulations and internal control systems, MNCs continue to engage in bribery, corruption and money-laundering and these practices are facilitated by the use of accounting to conceal them. The final section, Section 6, discusses the significance of corruption and its implications for development in developing countries.

\section{Unaccountable Accounting}

The preparation of financial statement (accounting) and auditing both the statements and accounts from which they are prepared are means of achieving accountability in society (Tinker, 1985). Accounting systems and the information that they presents are used to control a diverse range of institutional activities, including payment of tax obligations, control of cost in government contract. Obviously, accounting practices has been shaped by many forces other than for economic thinking. But marginalism has monopolised accounting thought in one specific sense (Tinker, 1985). Briloff (1972) argued that, 'one might then expect the implementation of procedures for assuring the corporation and its management the highest degree of visibility and accountability-so that all who are entitled to know will know, and thereby be able to make rational decisions. This expectation notwithstanding the situation, is very much otherwise' (p. 6). Accounting information facilitates the valuation of what is - or what might be - received through a configuration of exchange transactions. For example, the SEC (on behalf of community) gives social legitimacy and support to a corporation in exchange for behaviour that conforms to certain laws and norms. In all cases, accounting information helps parties to social and economic transactions assess the adequacy of the value of their returns or entitlements (Tinker, 1985).

The consistent use of accounting principles and procedures has long been considered essential in the evaluation of a firm's activities and in the projection of future activities (Tinker, 1985). While accounting is mostly viewed as a solution, it has also been implicated in facilitating corruption and other related financial criminal practices aimed at increasing profit/capital accumulation and reducing social obligations. It has been argued that anti-social financial practices are a regular occurrence in both developed and developing countries; and that accounting practices have played a key role in facilitating MNCs' pursuit of profits and earnings and capital accumulation by the elite (Briloff, 1981; Tinker, 1985; Bakre, 2007, 2011; Sikka, 2008; Compin, 2008). Compin (2008) noted that: 
'The positioning of accounting as a determinant element of financial crime presupposes that modern sophist excel at providing deceptive information whilst maintaining a semblance of rationality and economic credibility' ( $p .592$.

Paradoxically, bribery and corruption are part of broader business management, and however, these areas are colonised by accounting professionals because there are accounting numbers which characterised these activities and in turn increase corporate profits (Briloff, 1981; Tinker, 1985). Accounting numbers and information are constructed to accommodate different interests within an organisation (Latour, 1993). Reporting the 'facts' and 'taking account' inevitably enhances the interest of some groups over others. Hence, bribery and corruption are social and institutional practice that relies on accounting and entails accountability. Corruption and accounting therefore form an interpenetration of practices. According to Miller (1990):

'Accounting is a process of attributing financial values and rationale to wide range of social practices, thereby according them a specific visibility, calculability and operational utility' (p. 316-317).

This has been accompanied by a variety of strategies to improve corporate earnings through financial engineering, cartel, money laundering, bribery and corrupt practices (Briloff, 1981; Tinker, 1985; Sikka, 2008; Bakre 2007, 2011; Otusanya, 2010, 2011a). Veblen (1904) argued that those in control of large managerially governed corporations, attempted to promote the interest of capital by creating illusions (manipulating output, disseminating false reports and information, or withholding positive news) that affect exchange prices thereby recognising the power of accounting to affect the distribution of income between and within social classes. Social constituency accounting recognisees conflicts of interest, both within the corporation and between the corporation and other interest group. This therefore illustrates how an executive's moral concerns and altruistic desire must ultimately succumb to her corporation's overriding goals:

'If you're a CEO', 'do you think your shareholders really care whether you're Billy Buttercup or not? Do you think that they would prefer you to be a nice guy over having money in their pocket? I don't think so. I think people want money. That's the bottom line'. Greed and moral indifference define the corporate world's culture,...As pressure builds on CEOs to increase shareholder value, corporations are doing anything and everything they can to be competitive'. (Bakan, 2004, p. 55.)

The latter conflicts, or side effects, of corporate behaviour are often called externalities which include the usually negative effect of corporate activities on the well-being of community members outside the corporation, in situations in which they cannot obtain compensation through legal, contractual, or other means (Tinker, 1985). Tinker (1985) argued further that conflict over externalities (positive or negative) is merely a further example of struggle over distribution of income. Fundamentally, there is little difference among a firm that seeks to avoid the cost of safe treatment of toxic waste, a firm that uses fictitious financial statements to raise capital, and a firm that successfully disposes of its pension obligations to employees. These situations are identical in that they exemplify the struggle among different social constituencies over the distribution of income, a struggle in which accounting plays an important and substantial part (Tinker, 1985). Compin (2008) noted that: 
'The fiduciary currency and double entry bookkeeping formerly constituted the twin pillars of development of capitalism and helped make it the dominant economic system. However, the irrational exuberance of stock markets combined with repeated financial scandals have cast a cloud over an economic system.... The weakness of capitalism lies in its capacity to pervert both financial statement preparation and auditing, which constitutes accounting'. (p. 591.)

Accounting practices are essential in preventing and detecting bribery. Bribery often involves financial payment in one form or another, and it inevitably leaves behind a paper trail. Accounting is an information system that reports financial transactions and auditing serves as the monitoring and internal control mechanism-together they form a critical line of defence against corrupt practices. But poor financial information reporting systems can greatly undermine the firms' ability to detect and prevent bribery activities. As Briloff (1981) noted:

'The Pervasive 'fakes' produced in the corporate accountability environment-where the unsophisticated public has been led to believe that an effective system of checks and balances assures the accountability by the professional managers, the stewards of the wondrous pools of resources concentrated in our major publicly owned corporations'. ( $p$. 1.)

It was further stated that "compliance with generally accepted accounting principles is not necessarily sufficient for an accountant to discharge his public obligation. Fair presentation is the touchstone for determining the adequacy of disclosure and financial statements. While adherence to generally accepted accounting principles is a tool to help achieve that end, it is not necessarily a guarantee of fairness' (Briloff, 1981, p. 5). Therefore, the underlying principles of ensuring adequate reporting to enhancing good investment decisions can only be accomplished, if financial statements fully and fairly portray the actual financial condition of the company.

It has been argued that the Foreign Corrupt Practices Act $1977^{1}$ (FCPA 1977) was partly the result of lack of confidence in the accounting professions concern and ability to uncover illegal act of the US corporations abroad (Lehman, 1995). The accounting provisions of the FCPA were adopted to strengthen the system of corporate accountability. Accounting's failure to protect third party and the public interest has been reflected most recently in the latest global financial crises and bribery and corruption investigations. Tinker (1985) noted that accounting practice has helped cover up a number of financial scandals by large corporations, and in doing so, has encourage financial irresponsibility and mismanagement among multinational corporations.

Accounting and auditing are also essential in detecting bribery activities. Unusual and excessive expenditure may immediately raise the red flag on the possibility of bribery, and departure from the routine handling of financial transactions could also catch the attention of well-trained accountants (Briloff, 1981; Wu, 2005). Accountants are the first

\footnotetext{
${ }^{1}$ The genesis of the Foreign Corrupt Practices Act in the United States illustrates the detrimental impact of appropriative behaviour at the international level. The mid-1970s witnessed a series of bribery scandals involving US-bases multinationals, executives, military personnel, and politician of foreign government (Tinker, 1985, p. 196).
} 
set of gatekeepers to ensure that transactions are valid, at arms length, captured, and properly recorded according to the established standards (see Kimbro, 2003). The accounting profession is a major accomplice to this-perhaps biggest of allappropriation form the nation states. By failing to challenge the fictitious and fraudulent transactions shown in the financial statements of MNCs, auditors and accountants are keeping alive the prospect of the bribery and corruption in the corporate world. It has been suggested that the various bribery and corrupt practices prosecuted by SEC and DOJ in recent times all exposed the distributional impact of accounting, discrediting the profession's image of objectivity and impartiality and under-cutting its authority and credibility (Briloff, 1981).

Corruption in private sector (particularly, MNCs) can take place when top management decides to bribe government functionaries to get some benefits. In such situation, why would they ask their auditor to report on corruption? (Khan, 2006). Managers might pursue their own interest at the expense of the owner and other stakeholders of the firm. For example, 'securing a public project by bribing public officials may increase the compensation for the managers, but the firm could be held criminally liable for such action, and the owners and other stakeholders are forced to take the blame for the managers' actions' (Wu, 2005, p. 62). There could be situations in large public or private sectors organisations and in government department, where the rules and regulations are quite foolproof, yet corruption continue to flourish because of poor implementation. The auditor can point out these weaknesses as potential sources of corruption. The rules, regulations, procedures and operational standards of these organisations often leave lacunae, which create opportunities for corruption or at least protect corruption (Khan, 2006). Accounting rules, regulations and operational standards are only as good as the enforcement mechanism driving them, and the external auditors may align their interests with the corrupt corporate boards and managers by turning a blind eye to irregularities in accounting reports.

As finance capital has expanded, opportunities have increased for antisocial practices such as bribery and corruption (Sikka, 2008, 2010; Otusanya, 2010). As crime and criminals have become increasingly sophisticated, so too have their efforts to conceal money and assets worldwide, often beyond the reach of law enforcement. These were vividly exposed by the various investigations conducted by United States Securities and Exchange Commission (SEC) and Department of Justice (DOJ) into the activities of their MNCs operating in developing countries. The US SEC's report noted that:

'Bribery and corrupt payment were committed through the use of shell companies, secrecy havens, complex corporate structures and back-to-back financial documentation between MNCs and their affiliates in developing countries'.

The multiple layers of corporate structure can also be an obstacle to effective internal control of company. While the FCPA-induced regulatory framework where aimed at constructing a primary web of regulation, the supporting constraints on accounting calculations and the behaviour of managers and accountants differed from organisation to organisation. Internal control process within an organisation is designed to provide reasonable assurance which ensures a reliability and integrity of information and compliance with policies, plans, procedures, laws, and regulations. But, weak internal 
controls such as financial management, auditing, and personnel systems are also facilitating conditions. Even if the top management is committed to ethical business conduct, lower-level managers or employees may engage in corrupt practices to increase their short-term personal gain. Many MNCs have established subsidiary companies to penetrate market in developing countries, and there have been several high profile bribery cases involving these subsidiaries in recent years. This therefore suggests that the adoption of rules and regulations in accounting reforms should not be interpreted as equal to having good accounting practices. Herlihy and Levine (1976) therefore argue that:

'The accountant's failure to uncover the massive bookkeeping deficiencies that have been revealed should lead to a fundamental re-evaluation of the profession's role in preventing these abuses'. (p. 546).

This is because the FCPA 1977 emphasised the role of auditors in the disclosure process and stressed that the audit process is the foundation of corporate disclosure. Therefore, improvement on audit reliability is likely to increase public confidence in securities market (Vanasco, 1999). However, bribery and corrupt practices thrive on secrecy and through the use of accounting to conceal their trail (Sikka, 2008; Otusanya, 2010). As Briloff (1981) notes:

'The body of knowledge which the profession has evolved can lead to a fair presentation - most financial statements prepared in accordance with GAAP do provide a reasonable and responsible basis for decision making. But these very same precepts may be perverted and distorted in practice, so that we often paint fakes.... . (p. 8.)

This enterprise culture, which prioritises the commercial acumen of employees rather than ethical conduct, or even technical ability, becomes institutionalised, as the individual managers (professional) begins to internalise these value systems and norms (Sikka, 2008; Sikka and Hampton, 2005). These internalised practices and behaviours can be used to facilitate the anti-social corrupt practices of MNCs. A number of studies have blamed the management for the questionable and improper corporate behaviour and suggests measures to establish ethical and moral values in the work place and to prevent the recurrence of illicit overseas contracts (Vanasco, 1999; Otusanya, 2011a). The establishment and maintenance of system of internal control and accurate books and records as required by relevant provisions of FCPA 1977 and Securities and Exchange Act are fundamental responsibilities of management. Corporation could and have been held liable for corrupt payment made by their employees, even though not explicitly authorised (Miller, 1979; Briloff, 1981).

\section{Review of Related Cases}

This section examines the literature on the role of accounting in bribery and corrupt practices, a role which seems to deviate from their primary role as external watchdogs of shareholder wealth and as protectors of the public interest.

Accurate financial information reporting is essential to detect bribery and fraud, creative accounting reports have been widespread practices in private sector organisations. While it is widely believed that corrupt politicians and government officials are the bribe-takers, it is often the private sector (especially the corporate sector) that offers the bribe ( $\mathrm{Wu}$, 2005). Transparency International (2009) noted that: 
'The private sector plays a pivotal and expanding role in improving the well-being of societies, communities and individuals... the private sector can also fail on all these counts, however. It can enrich a few at the cost of many. It can disenfranchise, destabilise society and foster corruption, whether in communities, market, governments or international relations, ultimately undermining the prerequisites for its own existence'. (p. 3.)

Corruption in the private sector (particularly MNCs), regardless of which form it takes, usually involves a financial payments, which inevitably leaving a paper trail behind in accounting record (see $\mathrm{Wu}, 2005$ ). The SEC requirement states that corporations must devise and establish an internal control system that ensures that MNCs keep books, records, and accounts which accurately reflect the transactions and disposition of the issuers' assets.

It has been argued that market forces through greater competition will lead to less, rather than more, corruption (Rose-Ackerman, 1996; Ades and di Tella, 1999; World Bank, 1997). The World Bank (1997) was of the view that improving the functioning of markets would lead to a reduction in financial corruption:

'Markets will generally discipline participants more effectively than the public sector can, and their power to do so is closely linked to sound economic policy. Enlarging the scope and improving the functioning of markets will strengthen competitive forces in the economy and curtails rents, thereby eliminating the bribes public officials may be offered (or may extort) to secure them ${ }^{2}$.

In contrast to the above, globalisation and free market ideology has further contributed to corruption globally. In the 1970s, several editorials document the extent of illicit payments of bribe to foreign government in developing countries. According to Vanasco (1999) 'these scandals of corrupt foreign officials were reported almost daily by the press' (p. 162). For example, in 1975, Wall Street Journal documented a number of cases, United Brands Corporation made payments to high foreign official to obtain banana tax reduction in Honduras. Ashland Oil Company bribed foreign officials to obtain an oil drilling permit in Gabon. Lockheed Aircraft Corp. bribed lower and middle bureaucrats in 36 countries. It was disclosed at Senate hearing in 1975-76 that Lockheed had made more than $\$ 106$ million in secret 'commission' to promote foreign sales, including \$7 million to a well-connected Japanese agent who was also the head of a right-wing youth movement (Tinker, 1985). Exxon Oil Corp. offered kickbacks more than $\$ 50$ million to the Italian political parties and government officials in order to secure a natural gas contract and to buy favourable tax and energy legislation (Vanasco, 1999; Tinker, 1985). In 1976, the US Senate Committee on Banking, Housing, and Urban Affairs's hearings on illicit payments further revealed that several American concerns were engaged in bribing foreign officials or political parties to secure contracts abroad:

'Northrop Corporation paid foreign agents/consultants inflated fees or commission to pay officials in Saudi Arabia, NATO, and the Common Market countries. Lockheed Aircraft Corporation reportedly made payoffs in Germany, Italy, Turkey, Columbia,

2 The World Bank (1997), 'Helping Countries Combat Corruption: The Role of the World Bank', available on-line at http://www.worldbank.org/publicsector/anticorrupt/corruptn/cor05.htm accessed on 23 October 2006. 
Nigeria, Greece, South Africa, Japan, Saudi Arabia, Indonesia, and the Philippines. Gulf Oil Company made illegal Payments in South Korea, and Mobil Oil Corporation made illicit payments to Italian government officials' (Vanasco, 1999, p. 162)

These scandals were reported to have threatened US foreign policy and paved passage of the Federal Corrupt Practices Act 1977. Corporations are now required to disclose questionable payments, and as a result of such disclosure a number of MNCs are implicated. These include Boeing (\$500 million), General Tire and Rubber (\$41 million), Northrop (\$34 million), and many others (Tinker, 1985).

In addition, the US Conglomerate Baker Hughes Incorporated pleaded guilty to three charges of corruption and was fined $\$ 44$ million for hiring agents to bribe officials in Nigeria, Angola, indonesia, Russia, Uzbekistan and Kazakhstan. It was reported in these cases that companies devised several schemes to make illicit payments to foreign officials and political parties which include cash and non cash transactions. The expenses were accounted for under a variety of false and financial headings such as publicity and promotional expenses, fees paid to agents, consulting agreements advances to the corporation's foreign subsidiaries.

Corruption is a global phenomenon which requires both local and global solutions. A number of international initiatives ${ }^{3}$ have been established to criminalise the bribery of public officials (to address the supply side of corruption) and to provide mutual legal assistance. The corruption scandals of the 1970s involving illicit payments by US multinational companies (MNCs) and foreign politicians led to the passage of the US Federal Corrupt Practices Act (FCPA) in 1977 and this is examined in the following section.

\section{Anti-Corruption Regime in the United States}

The Foreign Corrupt Practices Act (the 'FCPA' or the 'Act') was enacted in 1977 in the wake of a series of overseas and domestic bribery scandals involving 400 major corporations. FCPA originally prohibited US corporations and US nationals from making improper payments to foreign officials, parties or candidates, in order to assist a company in obtaining, retaining or directing business to any person. It also imposed record-keeping and internal controls requirements on all companies subject to Securities and Exchange Commission ('SEC') jurisdiction. The FCPA and its amendment - the Trade and Competitive Act of 1988 - are unique not only in the history of accounting and auditing profession, but also in international law. As Vanasco (1999) notes:

'The Acts raised awareness of the need for efficient and adequate internal control systems to prevent illegal acts such as bribery of foreign officials, political parties and government to secure or maintain contracts overseas'. (p. 161)

The 1998 amendment expanded the jurisdiction of the US government to prosecute foreign companies and nationals who cause, directly or through agents, an act in

3 These includes; Federal Corrupt Practices Act 1977, OECD Anti-Bribery Convention 1997; UN Convention Against Corruption 2005, World Bank Anti-Corruption Strategies, and the UK Bribery Act 2010. 
furtherance of a corrupt payment to take place within the territory of the United States. In addition, US parent corporations may also be liable for the acts of foreign subsidiaries where they have authorised, directed or controlled the activity of US citizens or residents who were employed by or acting on behalf of such foreign incorporated subsidiaries. The FCPA contains two types of provisions:

'Anti-bribery provisions, which prohibit corrupt payments to foreign officials, parties or candidates to assist in obtaining or retaining business or securing any improper advantage; and record-keeping and internal controls provisions, which impose certain obligations on all companies whose securities are registered in the United States or which are required to file reports with the SEC, regardless of whether or not the companies have foreign operations'. (Federal Corrupt Practices Act, 1977, as amended.)

The Department of Justice ('DOJ') has primary responsibility for enforcing the antibribery provisions of the Act while the SEC generally enforces the accounting (books and records and internal controls) provisions. Both institutions have authority to seek permanent injunctions against present and future violations. In the process of constructing the new regulatory web, the accounting and auditing practice was enlisted to provide the necessary assurance of fairness in the conduct of MNCs business in developing nations. The FCPA's Books and Records and Internal Control provisions expressly states that:

'Books, records and accounts are kept in reasonable detail to accurately and fairly reflect transactions and dispositions of assets, and (ii) that a system of internal accounting controls is devised (a) to provide reasonable assurances that transactions are executed in accordance with management's authorisation; (b) to ensure that assets are recorded as necessary to permit preparation of financial statements and to maintain accountability for assets; (c) to limit access to assets to management's authorization; and (d) to make certain that recorded accountability for assets is compared with the existing assets at reasonable intervals and appropriate action is taken with respect to any differences'.

The importance of this provision can be appreciated when one considers the fact that in all jurisdictions companies are specifically required by law to publish their financial statements. To stress the importance of audit as part of the regulatory web, all corporations (whether local or MNCs) are required to have a sound internal control systems in ensuring the truth and fairness of transactions included in the financial statements. While the Books and Records and Internal Control provisions technically apply only to issuers and not to foreign subsidiaries, the enforcement agencies have hold parent companies liable for false or fraudulent entries on any book or record that is ultimately consolidated with an issuer's books and records for financial reporting purposes.

'Proof of a US territorial nexus is not required for the FCPA to be implicated against US companies and citizens, and FCPA violations can, and often do, occur even if the prohibited activity takes place entirely outside of the United States For this reason, business leaders must be knowledgeable about all business activity, including activity that takes place thousands of miles away from corporate headquarters'.

In many instances, improper payments to a foreign official to obtain or retain business result not only in anti-bribery charges, but also books and records and internal control charges, given that improper payments are often falsely characterised on a company's 
books and records as 'miscellaneous' expenses, 'commissions,' etc. and given the enforcement agencies' view that the improper payments would not have been made if the company had effective internal controls. Violations of the books and records and internal control provisions can also be charged in isolation even if anti-bribery violations are not charged. Vanasco (1999) noted that:

'The SEC's persistence to protect investors and its determination to file civil suits against US corporations that do not keep adequate record of their transactions for overseas operations or fail to devise and maintain an adequate system of internal control to detect and prevent improper payments ought to be of great concern not only to management and audit committees but also to internal and external auditors'. (p. 161).

The FCPA has constrained the role of not only of the audit committee but also that of the external auditor and internal auditor. In their audits, auditors must pay more attention to suspicious entries that might indicate possible questionable payment to foreign agent, consultants and foreign officials. Seidel (1980) noted that businessmen must be responsible for establishing an accounting control system that will inform them of what happens to their assets. The SEC recognised that 'the size of business, diversity of operations, degree of centralisation of financial and operating management, amount of contract by top management with day-to-day operations, and numerous other circumstances are factors which management must consider in establishing and maintaining an internal control system'

The FCPA also requires 'issuers' (any company including foreign companies) with securities traded on a US exchange or otherwise required to file periodic reports with the Securities and Exchange Commission ('SEC') to keep books and records that accurately reflect business transactions and to maintain effective internal controls (the "Books and Records and Internal Control Provisions). The accounting provision of the Act is administered and enforced by the Securities and Exchange Commission. The failure of public companies to disclose illicit payments in filings required by the securities laws can lead to prosecution by SEC. The Senate Report that accompanied the Securities Exchange Act of 1934 in the US stressed the importance that corporation file periodically reports with the Commission.

'Corporate reports are regarded as the minimum which is the requisite for adequate protection of investors. The committee has repeatedly heard testimonies illustrating the evasion, suppression, distortions, exaggerations, and outright misrepresentation practices by corporations with the intent to cloak their operations and to present to the investing public a false or misleading appearance as to financial condition'. (Quoting from, Vanasco, 1999, p. 199).

The report made it clear that SEC may order the disclosure of questionable payments because stakeholders have a right to be fully advised of facts concerning the character and integrity of officials relevant to their management of the corporation.

Individuals who commit wilful violations of the FCPA anti-bribery provisions may be punished by up to $\$ 250,000$ in fines and/or five years imprisonment. Individuals who violate the FCPA accounting provisions may be fined up to $\$ 5,000,000$ and imprisoned up to 20 years. Corporations may be fined up to $\$ 2,500,000$ per violation of the FCPA 
accounting provisions and $\$ 2,000,000$ for violation of the FCPA anti-bribery provisions. Moreover, under the Alternative Fines Act, these fines can be much higher: the actual fine may be up to twice the loss to the victim or benefit the defendant did or sought to obtain by making the corrupt payment. Fines imposed on individuals may not be paid by their employer or principal. An unlawful payment under the FCPA is not deductible under the tax laws as a business expense.

The FCPA also allows a civil penalty of up to $\$ 10,000$ against any firm that violates the antibribery provisions of the FCPA, and against any officer, director, employee, or agent of a firm who wilfully violates the anti-bribery provisions of the Act. The 1998 amendments eliminated a disparity in penalties between U.S. nationals who are employees or agents of issuers or domestic concerns and foreign nationals who are employees or agents of issuers or domestic concerns. While the Department of Justice has exclusive jurisdiction to prosecute criminal violations of the FCPA, both the Justice Department and the SEC may obtain injunctive relief to prevent bribery and recordkeeping violations of the FCPA.

It has been argued that despite the increased severity of the penalties adopted in FCPA 1977 and the Omnibus Trade and competitiveness Act 1988, US corporations do not seem deterred from bribing foreign officials to secure or maintain contracts overseas (see Vanasco, 1999). In the following section, some episodes of bribery and corrupt practices in developing countries are considered in order to show how MNCs and their corporate executives have exploited accounting practices for the purpose of furthering their financial interest.

\subsection{Methods}

This paper does not rely on a statistical sample in any positivistic sense because companies and individuals rarely provide information about their unethical and criminal corrupt practices and therefore the size of the populations cannot be determined in any meaningful way. Bribery and corruption are generally pursued away from the glare of public scrutiny and company financial reports are mostly silent on the issues. Rather it uses cases to illustrate the gap between conventional accounting and unaccountable or creative accounting to problematise the claim of corporate accountability.

Our analysis is based on an examination of the material produced by US Securities and Exchange Commission (US SEC) and US Department of Justice (DOJ) charged with the investigations of the United States Multinational Companies (MNCs) involvement in bribery and corruption in developing countries and the court charges. US DOJ and SEC conducted public hearings and testimonies were provided by auditors, accountants, managers and employees. The US DOJ and SEC also had access to a 'vast quantity of documentary evidence' which included: memos, emails, internal circulars, contract agreements, audit reports, meeting minutes and government publications. The SEC and DOJ report were of particular interest as these provided a way to follow the flow of bribe payment through a 'complex web of financial transaction and schemes aimed at leaving any trace in the official records. It also revealed the role accounting played in facilitating illegitimate flows. 
The SEC and DOJ generated a huge volume of documents and transcripts amounting to some hundred pages. These reports were available electronically and we specifically reviewed these reports for accounting-related information. It was from this set of publicly-available documentary evidence, as well as other secondary information that we were able to trace the illegal flow of funds and the recording of irregular accounting practices. It relies on episodes that have been brought to public attention by regulators, all of which are ascribed a certain kind of hardness by contemporary standards of evidence.

\section{Some Case Studies}

The SEC and DOJ prosecuted several companies for violation of the accounting provisions of the FCPA and for falsifying the accounting records as attested by the following cases.

\subsection{Case 1 - Willbros International}

Willbros Group conducted its operations outside of North America through its whollyowned subsidiary, Willbros International, Inc. Willbros International is incorporated in Panama and maintained its administrative headquarters in Tulsa until 2000, when it moved to Houston. Until it sold its Nigerian assets in February 2007, the company had conducted business in Nigeria for over 40 years -primarily through three affiliates ${ }^{4}$. Before the sale of Nigerian assets in 2007, the company's operations in Nigeria frequently represented a sizable percentage of the company's global revenues. In 2004, for example, the Nigerian operations produced roughly $25 \%$ of the company's global revenue. Willbros Group also conducted business in Ecuador through a subsidiary of Willbros International, known as Willbros Servicios Obras y Sistemas S .A. ('Willbros Ecuador'). In 2004, the company, through Willbros Ecuador, undertook a project called the Proyecto Santo Domingo ${ }^{5}$. In addition, it conducted business in Bolivia through a subsidiary of Willbros International, known as Willbros Transandina. In late 2001, the company, through Willbros Transandina's participation in a joint venture, obtained a $\$ 59$ million contract with a foreign consortium to construct a pipeline in Bolivia (the 'Yacuiba-Rio Grande project') (see Figure 1 below).

\footnotetext{
${ }^{4}$ Willbros West Africa, Inc., a wholly-owned subsidiary of Willbros International; Willbros Nigeria Ltd., a majority-owned subsidiary of Willbros West Africa; and Willbros Offshore Nigeria Inc., a majority-owned subsidiary of Willbros West Africa (SEC v. Willbros Group, Inc., et al. (2008), p. 5).

5 The client on this project was PetroComercial, a subsidiary of PetroEcuador. PetroEcuador is Ecuador's state-owned oil and gas company (SEC v. Willbros Group, Inc., et al. (2008), p. 5).
} 


\section{Figure 1 Willbros Subsidiary Network}

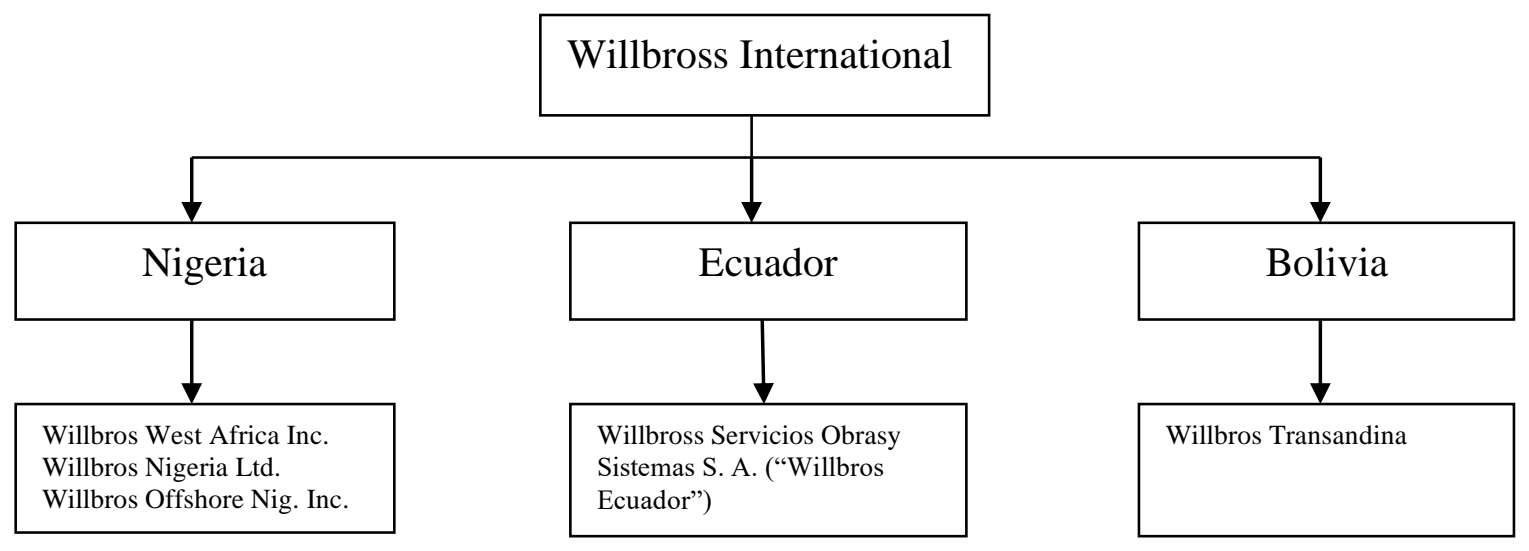

Source: Extracted from SEC v. Willbros Group, Inc., et al. (2008)

\subsubsection{Willbros Bribery Scheme in Nigeria}

From at least 2003 through early 2005, Willbros Group, through acts taken by various employees and officers of certain of its affiliates, violated the FCPA by authorising bribery schemes to make corrupt payments to foreign officials in Nigeria to assist in obtaining and retaining business for Willbros Group and its subsidiaries. The scheme entailed authorising the payment of over $\$ 6$ million in bribes to various officials to obtain at least two significant contracts. From these two contracts, Willbros Group realised approximately $\$ 8.9$ million in net profits (US District Court for the Southern District of Texas, 2008). The court judgement sheet states that:

'In 2003, during the EGGS project bidding process, the Former President of Willbros International and Steph, acting on behalf of Willbros Group, plotted with certain employees of Willbros West Africa's joint venture partner in the Willbros Nigerian Consortium, to make more than \$6 million in payments to Nigerian officials, a Nigerian political party and an official in the executive branch of Nigeria's federal government. These payments were intended to help the Willbros Nigeria Consortium obtain some or all of the EGGS business'. (US District Court for the Southern District of Texas, 2008, p. 7).

Therefore, to implement the scheme, the former President of Willbros International caused Willbros West Africa to enter into sham 'consultancy agreements' ${ }^{6}$ with an outside consultant in Nigeria ('Consultant 1'), whose company invoiced Willbros West Africa for purported 'consulting' services. The invoices were submitted by Jansen and others to the company's administrative office in Houston for payment by wire transfer to

\footnotetext{
${ }^{6}$ The 'consultancy agreements' called for the payment, in exchange for purportedly legitimate consulting services, of 3\% of the contract revenue for certain projects, including the EGGS project (US District Court for the Southern District of Texas, 2008).
} 
a foreign bank, as directed by the invoices. To further conceal the unethical financial practices, the court judgement noted that:

'The wired money was purportedly for the legitimate consulting services provided to Willbros affiliates, but, in fact, some or all of that money was intended for corrupt payments.... The money disbursed to the 'consultant 1' was improperly recorded in Willbros Group's books and records as legitimate consulting expenses or other business expenses. Through this scheme, a portion of these so-called "commitments" had been paid by late 2004'. (US District Court for the Southern District of Texas, 2008, p. 8.)

In 2005, the company's audit committee commenced an internal investigation into allegations of tax improprieties concerning Willbros Transandina, a subsidiary operating in Bolivia under the management of the Former President of Willbros International. The internal investigation was extended in scope to include activities in Nigeria. As a result of the company's internal investigation, the 'consulting' agreements with Consultant 1's companies were terminated and further payments to Consultant 1 ceased. Yet, Brown and Steph, in concert with employees of their joint venture partner, met with a Nigerian consultant ('Consultant 2') and determined to resume the payments. It was reported that, Brown and Steph agreed to pay $\$ 1,850,000$ toward the outstanding 'commitments'. Because they could no longer generate money by submitting invoices from Consultant l's companies, Steph and others engaged in the scheme sought alternative sources (US District Court for the Southern District of Texas, 2008). The judgement sheet stated that:

'They agreed on several potential funding sources: (1) a loan from principals of a Nigerian oil and gas company ('Company 1') to one of Willbros's Nigerian subsidiaries; (2) a loan from the company's Willbros Nigeria Consortium partner to one of Willbros's Nigerian subsidiaries; and (3) petty cash from a local account maintained by one of Willbros's Nigerian subsidiaries'. (US District Court for the Southern District of Texas, 2008, p. 9.)

Shortly thereafter, Brown, on behalf of Willbros West Africa, agreed to borrow, pursuant to a written loan agreement, $\$ 1$ million from the company's partner in the Willbros Nigeria Consortium. He then 'loaned' the money to Consultant 2, for delivery to Nigerian officials. Steph participated in the plan to fund the "commitments" and knew of Brown's actions. To further help procure the $\$ 1,850,000$, Steph borrowed, in Nigerian currency, the equivalent of roughly $\$ 500,000$ from another individual, working through a Nigerian oil and gas company. He then delivered that money to Consultant 2 to be transferred to Nigerian officials (US District Court for the Southern District of Texas, 2008).

In addition, Steph directed that the equivalent of approximately $\$ 350,000$ be procured from a Willbros cash account in Nigeria; Steph requested this money to transfer it to Consultant 2 for delivery to Nigerian officials. This money was accumulated using fictitious invoices to falsely inflate weekly funding requests transmitted to Willbros Group's Houston administrative headquarters. After obtaining the $\$ 350,000$, Steph transferred it to Consultant 2 for delivery to the Nigerian officials (US District Court for the Southern District of Texas, 2008).

In order to reduce this tax obligation, employees of Willbros affiliates bribed auditors responsible for determining the amount of tax owed. In addition, Willbros International 
employees in Nigeria also paid clerks and other officials within the Nigerian judicial system in exchange for favourable treatment in pending cases. The Court judgement sheet states that:

'These payments to court and tax officials were disguised within the company's petty cash processes in Nigeria. Certain employees of Willbros Group's subsidiaries requisitioned excess petty cash funds by submitting fictitious invoices from non-existent vendors. For example, Jansen and Biggers inflated the cash needed by obtaining fictitious invoices, typically for fuel, freight or catering expenses, from non-existent vendors. Jansen used these fictitious invoices to inflate the anticipated expenditures that he projected in weekly forecasts that he prepared or that were created under his direction'. (US District Court for the Southern District of Texas, 2008, p. 11.)

These artificially inflated reports were used to obtain cash (ultimately over $\$ 6$ million) from the company's offices in Houston. At least $\$ 300,000$ of this money was used to make payments to Nigerian tax and court officials. The Former President of Willbros International knew of these schemes and approved them, either explicitly or implicitly. The trace of the flow of the funds, revealed the role accounting played in facilitating the corrupt payment. The Court judgement stated that company executives knowingly facilitate corrupt payment:

'As part of this scheme, Jansen routinely approved for payment invoices he knew were false. He also knowingly submitted false cash requests and forecasts, knowing that those false reports would generate fund that would at least in part by used to bribe Nigerian court and tax officials. Biggers knowingly procured invoices he knew to be false and that he knew would be used to procure funds that would be used to bribe Nigerian court and tax officials. Finally, Steph knew about this conduct and approved it, both tacitly and on some occasions explicitly'. (US District Court for the Southern District of Texas, 2008, p. 12.)

From at least the early 1990's through 2005, employees of Willbros Group or its affiliates in Nigeria abused petty cash accounts to, among other things, make repeated bribes to Nigerian tax and court officials. The court judgement and allegation of bribery payment also raise questions about the efficiency of internal control systems and auditing process (US District Court for the Southern District of Texas, 2008).

\subsubsection{Willbros Bribery Scheme in Ecuador}

In Ecuador, the Former President of Willbros International orchestrated, in violation of the FCPA, a promise to pay $\$ 300,000$ in bribes to officials of PetroEcuador, an oil and gas company wholly-owned by the government of Ecuador, and its subsidiary, PetroComercial. The bribes were made to influence the awarding of a contract that ultimately generated total revenues exceeding $\$ 3$ million. The Court indictment sheet states that:

'The Ecuador employee telephoned Brown and informed him that the company could obtain a $\$ 3$ million contract to modify a pipeline running from Santo Domingo to El Beaterio, Ecuador ('the Santa Domingo Project'), if the company would agree to pay $\$ 300,000$ (10\% of the contract value) to certain officials of PetroEcuador, an oil-and-gas company wholly-owned by the government of Ecuador, and its subsidiary, PetroComercial (collectively, 'PetroEcuador'), and the sum were to be made in two equal instalments'. (US District Court for the Southern District of Texas, 2008, p. 12).. 
With approval from the Former President of Willbros International, Brown and the Ecuador employee agreed to make, on behalf of Willbros Group and its affiliates, the payments. It was reported that between the January and June 2004 time period, the Former President of Willbros International, on the company's behalf, communicated by e-mail and telephone with Brown to arrange the transfer of $\$ 150,000$ to employees of Willbros Ecuador so that they could deliver the money to PetroEcuador officials. One or more of these e-mail communications were sent from Brown in South America through Willbros Group's server located in Houston, Texas. In June 2004, the Former President of Willbros International directed an outside consultant to wire $\$ 150,000$ to the bank account of a second Willbros Ecuador employee, so that the money could be then be used to make the payments to the PetroEcuador officials (US District Court for the Southern District of Texas, 2008). The Court indictment states that the payments were concealed in the book of Willbros:

'The money for these payments was transferred to the private bank accounts of Willbros Ecuador employees and their family members. These disbursements were falsely recorded in the company's books and records as 'consulting expenses', 'platform expenses', or as 'prepaid expenses'. (US District Court for the Southern District of Texas, 2008, pp. 13-14. )

The company ultimately performed the Santa Domingo project, and made roughly $\$ 3.4$ million in revenue. When the bribes pertaining to the second project were discovered in 2005 , the company relinquished the project.

\subsubsection{Willbros Bribery Scheme in Bolivia}

Willbros conducted business in Bolivia through Willbros Transandina, S.A., a subsidiary of Willbros International. In late 2001, Willbros Transandina, as part of a joint venture, was awarded a contract to complete a pipeline in Bolivia. Willbros Group, through the actions of others, including the former President of Willbros International and a United States citizen serving as an outside consultant (the 'outside consultant'), devised and implemented a scheme to minimize Willbros Transandina's VAT obligation by using fabricated invoices to Bolivian vendors as 'offsets'. This was accomplished by acquiring invoices that reflected fictitious transactions; these invoices were then used to support tax returns that fraudulently claimed unearned VAT tax offsets (US District Court for the Southern District of Texas, 2008). The court indictment sheet states that:

'In many cases, the outside consultant procured the fictitious invoices. Galvez, as the incountry accountant and administrator for Willbros Transandina, acting under the direction of the Former President of Willbros International, used the fictitious invoices to further the scheme by, among other things, preparing false returns and related records'. (US District Court for the Southern District of Texas, 2008, p. 15.)

It was reported that rather than funding consulting services, however, these funds were spent, at least in part, to procure the fictitious invoices and to otherwise support the fraudulent tax minimization strategy. In 2004 alone, Willbros Group paid more than $\$ 500,000$ to the outside consultant. As a result of this scheme, the contract costs and the VAT liabilities to the Bolivian government for fiscal years 2002, 2003 and 2004 were materially understated; the scheme effectively inflated Willbros Group's net income by 
approximately $6.4 \%$ in fiscal year 2003 and inflated earnings per share by approximately $\$ .03$ for both fiscal year 2003 and the first three quarters of 2004 .

In addition to VAT, the Bolivian government levies an income tax on foreign companies doing business in Bolivia through a 12.5 per cent withholding tax ('Foreign Withholding Tax'). Willbros Group, primarily through conduct by the Former President of Willbros International, materially understated its Foreign Withholding Tax liabilities during the fiscal years 2002, 2003, and 2004. During these periods, the Former President of Willbros International, accounting personnel eliminated the Foreign Withholding Tax liabilities from Willbros Group's books and records, by reducing the tax liability account to offset cash disbursements made to the outside consultant and others. In reality, there was no legitimate tax saving strategy. Instead the funds were merely used to benefit the purported outside consultant and others. These actions and the resulting false records caused the tax liability to be understated. As a result, for fiscal year 2003, these understatements caused Willbros Group's net income to be inflated by approximately 6.4 per cent. This scheme resulted in material misstatements in the financial statements which Willbros Group included within certain Commission filings ${ }^{7}$.

As a consequence, the Willbros Group and its subsidiary, Willbros International Inc., accepted responsibility for its employees who had violated the FCPA 1977 and agreed to pay $\$ 22$ million by way of fines in connection with the corrupt payment to the Nigerian, Ecuadoran and Bolivian Government Officials (US SEC Litigation Release, 14 May 2008; US Department of Justice Release, 14 May 2008). This case also illustrates the use of bribery to secure competitive advantages, and increased profits. While the larger bribes were used for securing government contracts, others were used to obtain a reduced tax liability in Nigeria, Ecuador and Bolivia, and to secure favourable treatment in pending cases in Nigeria. The Court transcript revealed that Willbros used shell companies in the form of consultancy firms and agents with no actual business with the company other than to distribute the bribe to the beneficiaries. These predatory practices are disguised in the companies' accounts through the use of fictitious accounting transactions. The following case explores another bribery scandal involving a US company in sale of goods to the United Nations.

\subsection{Case 2 - Armor Holdings, Inc. and U.N. Bribery Scheme}

Armor Holdings, Inc., during the relevant period, was a Delaware corporation, headquartered in Jacksonville, Florida, whose operating subsidiaries specialised in the manufacture and sale of military, law enforcement, and personnel safety equipment. Armor Holdings Products, LLC ('AHP'), is a wholly-owned subsidiary of Armor Holdings, and a Delaware limited liability company with headquartered in Jacksonville, Florida. While Armor Products International, Ltd. ('API'), is a wholly-owned UK subsidiary of AHP. API's financial results were consolidated into AHP's financial statements which, in turn, were consolidated within the financial statements of Armor Holdings (US District Court for the District of Columbia, 2011).

\footnotetext{
${ }^{7}$ This material misrepresentations violates Section 17(a) of the Securities Act of 1933 ("Securities Act") and Section 10a of the Exchange Act and Rule 10b-5 thereunder, along with the books and records, internal controls and reporting provisions of the Exchange Act.
} 
The agents of Armor Holdings ${ }^{8}$ caused API to enter into a sham consulting agreement with a third-party intermediary for purportedly legitimate services in connection with the sale of goods to the U.N. API agreed to pay the intermediary a success fee in the form of a percentage of value of any contract obtained from the U.N. The SEC complaint reports that:

'From 2001 through 2006, certain agents of Armor Holdings participated in a bribery scheme in which corrupt payments were authorized to be made to an official of the United Nations ('U.N.'), for the purpose of obtaining and retaining U.N. business'. (US District Court for the District of Columbia, 2011, p. 1).

Furthermore, it was also reported that from 2001 through June 2007, another Armor Holdings subsidiary employed an accounting practice that disguised in its books and records approximately $\$ 4,371,278$ in commissions paid to intermediaries who brokered the sale of goods to foreign governments. The SEC complaint states that:

'Between 2001 and 2006, API received various invoices from the third-party intermediary. The intermediary charged API inflated or illegitimate commissions for its purported consulting services - reaching as high as twenty percent of the amount to be earned on the original contract'. (US District Court for the District of Columbia, 2011, p. 3.)

Agents of Armor Holdings knew or consciously disregarded that some portion of these commissions would be offered to a U.N. official. In late September 2001, the third-party intermediary obtained a confidential internal U.N. memorandum recommending that API be awarded the contract. It was noted in the SEC complaint that:

'In October 2001, the U.N. awarded API a multi-year contract for the supply of body armor. API's ability to secure this business was facilitated by the intermediary's inside access within the U.N. procurement system'. (US District Court for the District of Columbia, 2011, p. 4.)

In February 2003, an AHP vice president asked the third-party intermediary how API could win a renewal contract to -sell body armor to the U.N. The intermediary responded that the same rules would apply to the 2003 tender as applied to the 2001 tender. In August 2003, API received another three-year contract from the U.N. In 2006, API received an additional one-year supply extension from the U.N., without further assistance from the third-party intermediary. Such an extension was contemplated by the 2003 contract. It was therefore reported that:

'By late 2006, API had made at least ninety-two payments to the U.N. intermediary, totaling approximately \$222,750. Agents of Armor Holdings caused API to wire payments to the intermediary with the understanding that part of these payments would be offered to a U.N. official who could help steer business to API. From the 2001 and 2003 U.N. body Armor contracts -together with the one-year extension granted in 2006 Armor Holdings derived gross revenues of approximately \$7,121,237, and net profits of approximately \$1,552,306’. (US District Court for the District of Columbia, 2011, pp. 56.)

\footnotetext{
${ }^{8}$ AHP vice president and an API senior officer, agents of Armor Holdings, participated in a scheme to help API obtain contracts for the supply of body armor to be used in U.N. peacekeeping missions.
} 
The SEC complaint further notes that from in or around 2001 through June 2007, AHP also employed a separate accounting practice (hereinafter described as 'distributor net') to disguised in the books and records of Armor Holdings roughly \$4,371,278 in sales commissions paid to third-party intermediaries who brokered the sale of goods to foreign governments.

Since the sales intermediaries never obtained title over the goods, and AHP retained the risks and rewards of ownership prior to delivery, U.S. Generally Accepted Accounting Principles ('GAAP') required AHP to record sales to foreign governments at the full or 'gross' sales price -with a separate display of any commission expense for amounts paid to an intermediary. In contracts to these general accounting principles, AHP adopted the 'distributor net' accounting practice which disguised certain commission payments to sales intermediaries in the books and records of Armor Holdings. The SEC complaint specifically noted that:

'In a typical 'distributor net' transaction, AHP sent the foreign-government customer a 'gross' invoice-including the sales price of goods sold, plus commission while internally recording sales at a 'net' amount that did not include the commission due to the thirdparty sales intermediary. Thus, amounts received from the customer would be greater than the amount booked internally for a sale, resulting in a credit balance in the customer's account receivable. AHP would then transfer the 'overpayment' through a series of non-commission accounts before ultimately disbursing it to the third-party sales intermediary'. (US District Court for the District of Columbia, 2011, p. 5.)

Hence, these payments to sales intermediaries under 'distributor net' accounting were never recorded as a commission expense on the books and records of Armor Holdings. The largest 'distributor net' deal involved a sale of body armor vests to the Iraqi government. In this 2005 transaction, an Armor Holdings subsidiary submitted 'gross' invoices totaling \$3,364,532 through an intermediary in the U.K. Rather than record the transaction at the 'gross' amount, AHP booked the sales and accounts receivable at the 'net' amount of $\$ 2,220,000$. AHP then recorded much of the $\$ 1,144,532$ 'overpayment' in unrelated accounts before disbursing commissions to two sales intermediaries. The effect of 'distributor net' accounting for this transaction was to conceal over $\$ 1$ million in commissions on the books and records of Armor Holdings. The use of 'distributor net' accounting system was actually condemned by the external auditor of Armor Holdings thus:

'Armor Holdings was on notice that AHP's 'distributor net' accounting was improper. For example, on March 12, 2001, Armor Holdings' outside auditor emailed comments to certain senior officers, indicating that the 'distributor net' practice understated accrued liabilities and accounts receivable; and that the company should record a receivable for the gross amount due, together with an accrual for commissions'. (p. 6.)

In addition to the notice by the external auditor, one of the Armor Holdings subsidiary comptrollers also criticised the use and the application of 'distributor net' accounting system:

'On September 22, 2005, the comptroller of another Armor Holdings subsidiary who had refused to implement 'distributor net' at his division advised senior officials at AHP and Armor Holdings of his concern that such accounting was 'blown out of the water' by GAAP. Because AHP acted as a manufacturer rather than a distributor, the comptroller 
believed 'it would be wholly inappropriate, based on the guidance in EITF [Emerging Issues Task Force] 99-19 to record the revenues net'. (US District Court for the District of Columbia, 2011, p. 6.)

SEC complaint states that despite the criticisms against the use of this accounting method that contradict the GAAP in the US, AHP continued to employ 'distributor net' accounting through June 2007. It was therefore reported that AHP used 'distributor net' accounting in at least 92 transactions from 2001 through June 2007 -resulting in approximately $\$ 4,371,278$ of undisclosed commissions on the books and records of Armor Holdings, and rendering those books and records inaccurate (US District Court for the District of Columbia, 2011).

As a consequence, Armor Holdings, was indicted and charged for failure to ensure effective internal controls system and the application of 'distributor net' method of accounting for illegal commission paid to third parties in the scheme. The SEC therefore filed a settled civil enforcement action against Armor Holdings, Inc., alleging violations of anti-bribery, books and records, and internal controls provisions of FCPA. Armor Holdings, latter reached a settlement with the US SEC and agreed to pay a total of $\$ 5,690,744$ in disgorgement, prejudgment interest, and civil penalties in order to resolve the commission's charges (SEC Litigation Release, 13 July 2011). In a related matter, Armor Holdings entered into an agreement with DOJ to pay a $\$ 10,290,000$ penalty to the US Department of Justice to resolve violations of the FCPA (Department of Justice, 13 July 2011).

\subsection{Case 3 - Johnson and Johnson ( J \& J)}

Johnson \& Johnson ('J\&J') is a global pharmaceutical, consumer product, and medical device company headquartered in New Brunswick, NJ. Its securities are registered with the Commission under Section 12(b) of the Exchange Act, and its common stock trades on the New York Stock Exchange under the symbol 'JNJ'. J\&J operates worldwide through more than 250 operating companies. J\&J and its subsidiaries employ more than 100,000 people. In fiscal year 2009, its sales totalled $\$ 61.8$ billion (United States District Court for the District of Columbia, 2011).

J\&J through its seven subsidiaries ${ }^{9}$ were alleged to have violated the Securities Exchange Act of 1934 and the FCPA of 1977 by making illicit payments to foreign government officials in order to obtain or retain business in four different countries (Greece, Poland, Romania and Iraqi) (see Figure 2 below).

\footnotetext{
9 These subsidiaries were located in Delaware, Britain, Greece, Poland, Romania, Switzerland and Belgium.
} 
Figure 2 Johnson and Johnson Subsidiary Network

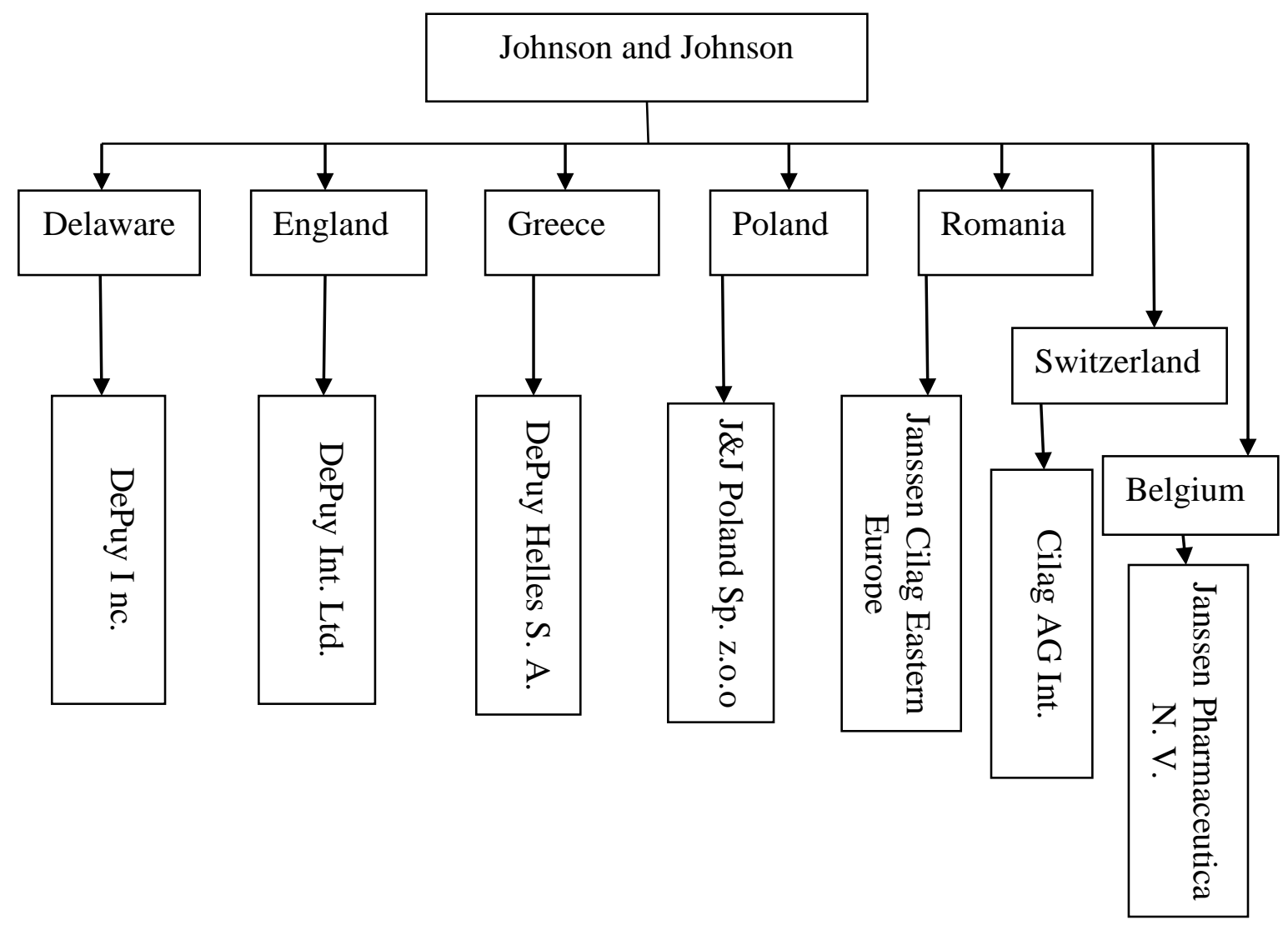

Source: Extracted from SEC v. Johnson and Johnson (2011)

\subsubsection{Bribery Scheme in Greece}

One of the J\&J's product lines is surgical implants ${ }^{10}$ such as artificial knees, hips and other products that surgeons implant into patients. In 1998, J\&J acquired another medical device company, DePuy Inc., a NYSE company. It was reported that at the time of acquisition, DePuy was engaged in widespread bribery scheme in Greece to sell its implants. Executive $\mathrm{A}^{11}$ and DPI executives knowingly continued that scheme. From 1998 to 2006, J\&J earned $\$ 24,258,072$ in profits on sales obtained through bribery (United States District Court for the District of Columbia, 2011). According to the SEC complaint, DPI executed two contracts to memorialise the deal:

'In September 1997, DPI hired the Greek Agent's, Greek company (the Greek Distributor) as its exclusive sales agent. Under that deal, the Greek Distributor agreed to market DePuy products in Greece and to pay DPI for products that it re-sold primarily to

${ }^{10}$ Surgical implants are a lucrative business. In many countries, orthopaedic surgeons control which implants they used (p. 4).

${ }^{11}$ Executive A, is a top DePuy executive who went to become a top J\&J executive in the United States in $\mathrm{J} \& \mathrm{~J}$ medical device and diagnostics business. 
public hospitals. A month later, DPI signed a separate contract with a private company in the Isle of Man (the private company) owned by the Greek Agent in which DPI agreed to pay the private company a 25 per cent commission on everything that the Greek Distributor purchased.....the second contract states that the private company would provide marketing support to the Greek Distributor and DPI', (p. 5).

The SEC complaint states that the contacts were a sham engineered to facilitate bribery. DPI inflated the price it charged the Greek Distributor, then paid that 'commission' to the private company. The private company did not provide any significant services to DPI. The Greek Agent used the commissions which were raised to 35 per cent by 1988 - to bribe publicly employed doctors to use DePuy implants (United States District Court for the District of Columbia, 2011).

After the merger, J\&J executives learned that the Greek Agent was being paid through a private company in the Isle of Man. These payments violated the PBC's policy requiring all agent payments be made in the country where the product was sold, i.e., in Greece. DPI executive were particularly concerned that the payments made out of country would raised red flags of bribery. As a consequence, by April 1999, it was reported that certain $\mathrm{J} \& \mathrm{~J}$ executives decided to stop the payments to the Private Company in the Isle of Man over the objection of Executive A (United States District Court for the District of Columbia, 2011). Contrary to the above decision, Executive A notes that terminating the Greek Distributor would affect their performance:

'[t]he only problem with the proposal was that we would lose half our business even by year 3' Executive A stated that [t]o lose approximately $\$ 4$ million in sales in end user terms to the competition is totally unacceptable'. (p. 7)

The DPI executives then met with the Greek Agent to discuss their future business arrangements. It was reported that Executive A tried to reinstitute the payments in the Isle of Man, but after a J\&J attorney objected, Executive A allowed DPI to acquire the Greek Distributor instead. The negotiation towards buying the Greek Distributor raised more red flags of bribery, yet DPI lawyer and accountant draft of due diligence report states that they had not seen evidence of bribery in the Greek Distributor books and could not determine whether the Greek Distributor engaged in these practices. However, the Greek Distributor's outside accountant e-mailed the DPI financial executive stating that:

'The Greek Distributor's inventory was overvalued by 35 per cent and would have to be adjusted after DPI's acquisition when the inventory was valued and rolled up to J\&J's books and records'. (p. 7.)

The e-mail noted that the Greek distributor had paid inflated prices to fund the payments to the Private Company and to cover 'cash incentives that the Greek Agent paid. The email alerted the DPI accountant to the bribery, but he never changed his due diligence report (United States District Court for the District of Columbia, 2011). It was further reported that several DPI executives knew that 'cash incentives' were not proper and that they were really bribes to doctors. To further conceal the illicit payments, J\&J finally closed DPI's acquisition of the Greek Distributor in January 2001 and renamed it DePuy Helles. The Greek Agent's associate became the head of DePuy Helles. The report states that rather than sever its ties to the Greek Agent, DePuy Helles continue to use him as consultant to facilitate bribe payments: 
'To conceal the true purpose and amount of payments subsequently made to Greek Agent, the DPI executives split the payments between two new agreements with some payments paid by DPI and others paid by DePuy Helles. The bribe payments to doctors continued, and the Greek Agent and DPI executives often referred to them as 'professional education' and 'support'. (p. 9)

In October 2003, DPI dismissed the Greek Agent after months of disputes about the sales of surgical implants in Greece. As a result, DPI hired another agent to fill the same role in the bribery scheme. In 2005, considering the effect of a new EUCOMED Code of Business Practice, DPI vice president wrote to the head of DePuy Helles and his supervisor:

'Everyone in the industry is a million miles from applying the letter or sprit of the EUCOMED code! Most industry players break every single rule in the book (support spouse travel, given non-medical gifts, etc.). If we applied the letter and intent of the guidelines today, we would lose 95 per cent of our business by the end of the year'. (p. 10).

It was therefore reported that from 2002 to 2006, records show about $\$ 590,000$ in large, round-number withdrawals booked as 'miscellaneous'. Those amounts were generally redeposited to a petty cash within days and were booked as 'prepayments' (p. 10). The J\&J's internal audit group discovered the payments to Greek doctors in early 2006 after receiving a whistleblower complaint (United States District Court for the District of Columbia, 2011).

\subsubsection{Bribery Scheme in Poland}

The SEC complaint noted that the employee of MD\&D Poland, and J\&J subsidiary, through sham contracts, travel documents and slush funds bribed publicly-employed doctors and hospital administrators to obtain business. From 2002 to 2006, J\&J earned $\$ 4,348,000$ in profits from its sales through the bribery. It was reported that MD\&D Poland created a sham civil contract publicly-employed doctors and hospital administrators:

'To pay them for using J\&J's medical devices or for influencing hospitals to award medical device to MD\&D Poland. Although the contracts called for services, the doctors would not provide any, and MD\&D Poland would pay the doctors based on fictitious activities'. (p. 11).

Approximately, between 2002 and 2006, \$775,000 of improper civil contract payments were funnelled to public doctors. It was noted in the report that, MD\&D Poland had no internal controls in place that would have required supporting documentation be provided prior to making the payment to the doctors. In addition, MD\&D Poland employees also faked travel expenses in order to generate cash. The money was then funnelled to doctors as bribe payments. For example, two MD\&D franchises used a particular travel agency to funnel money to a senior Poland Ministry of Health official with significant influence over a hospital. MD\&D Poland was reported to have spent approximately $\$ 7.7$ million on these travel sponsorship between 2000 and 2006 that were rolled into the books of J\&J with an indeterminate amount as bribes due to insufficient records (United States District Court for the District of Columbia, 2011). 


\subsubsection{Bribery Scheme in Romania}

The SEC complaint reports that employees of J\&J d.o.o. ('Pharma Romania'), a J\&J subsidiary, bribed publicly-employed doctors and pharmacists to prescribe and ordered J\&J products for their patients. From 2000 to 2007, J\&J earned \$3,515,500 in profit from its sales through the bribe (United States District Court for the District of Columbia, 2011). According to the SEC Complaint:

'Pharma Romania employees or the distributors would then deliver the cash to the doctors that were equal to 3-5 per cent of the cost of the drugs that they prescribed. The distributors would then work with the doctors and pharmacies to deliver the drugs to patients and receive payment for the drugs from Romanian government insurance program'. (p. 13).

Due to J\&J's internal audit on claims of cash payments to doctor, Pharma Romania introduced another scheme by offering the doctors trips to medical congresses in return for the doctors prescribing promotional products. It was noted that in some cases, Pharma Romania employees and J\&J's travel agents overcharged Pharma Romania for trips in order to generate cash to pay for the doctors' family to attend the trips as vacations or to provide the doctors with 'pocket money' while on the trips (United States District Court for the District of Columbia, 2011).

\subsubsection{Bribery Scheme in Iraq}

The Oil for Food Program ${ }^{12}$ (the 'Program') was intended to provide humanitarian relief for the Iraqi population, which faced severe hardship under the international trade sanctions that followed Iraq's 1990 invasion of Kuwait. The program permitted the Iraqi government to sell its crude oil and use the proceeds to purchase food, medicine, and critical infrastructure supplies (United States District Court for the District of Columbia, 2011).

It was reported that corruption was rampant within the program. By mid-2000, Iraqi ministries on the instruction of top government officials instituted a policy requiring suppliers of humanitarian goods to pay a ten per cent kickback on each contract. This kickback requirement was euphemistically referred to as an 'after-sales service' fee, however, no services were provided. Suppliers competing to obtain contracts under the program were encouraged to include a ten per cent mark-up in their bids or purchase orders. The inflated contract prices were incorporated into the Oil for Food contracts as a way to permit the suppliers to recover from the U. N. Escrow Account the kickback payments they had paid secretly to Iraq ${ }^{13}$ (United States District Court for the District of Columbia, 2011).

\footnotetext{
12 The proceeds of the oil sales were transferred directly from the buyers to an escrow account (the 'U.N. Escrow Account') maintained in New York by the United Nations 661 Committee. Funds in the U.N. Escrow Account were available for the purchase of humanitarian supplies, subject to U. N. approval and supervision (p. 14).

${ }^{13}$ Following the 2004 release of a report by the U.S. General Accounting Office exposing some of the abuses, estimated that the Iraqi government had diverted $\$ 1.7$ billion in illicit income from the program (United States District Court for the District of Columbia, 2011, p. 15)
} 
J\&J participated in the Program through two of its subsidiaries, Cilag AG International and Janssen Pharmaceutica N. V. (collectively 'Janssen-Cilag'). It was reported that during the Program, Janssen-Cilag sold pharmaceuticals to an arm of the Iraqi Ministry of Health Known as Kimadia. Janssen-Cilag conducted business with kimadia through a Lebanese agent. The Agent's primary contact with J\&J companies was an area director at Janssen-Cilag's office in Lebanon. In February 2001, several months after Kimadia started demanding kickbacks, Janssen-Colag signed 'side letters with the Agent that raised his commissions on sales in Iraq by ten per cent to twenty-two per cent. The report notes that:

'The increase in the Agent's commission was approved by a Janssen-Cilag area director in Lebanon as well as managing director for Janssen-Cilag's Middle East West Asia (MEWA) group in Belgium. The reason for the increase was so that the Agent could conduct 'promotional activities' in Iraq..... on behalf of Janssen-Cilag to pay the required ten per cent kickbacks to the Iraqi ministries through the agent and to mask the payments as legitimate agent commission in the companies' books and records'. (p. 16).

In total, secret kickback payments of approximately $\$ 857,387$ were made in connections with nineteen Oil for Food contracts. The payments were made through the Agent to Iraqi controlled accounts in order to avoid detection by the U. N. The fee was effectively a bribe paid to the Iraqi regime, which were disguised on J\&J's books and recorded by mischaracterising the bribe as legitimate commissions (United States District Court for the District of Columbia, 2011). In order to generate funds to pay the bribe and to conceal these payments:

'Janssen-Cilag and its agent inflated the price of the contracts by at least ten per cent before submitting them to the U. N. for approval. J\&J's total profits on the contract were $\$ 6,106,255^{\prime}$ (p. 17).

$\mathrm{J} \& \mathrm{~J}$ through its subsidiaries and agents were accused of knowingly allowed its employees and third parties to pay Greek and Polish public doctors and public hospital administrators and the Iraqi government ministries for the purpose of obtaining or retaining business. In addition, Polish doctors were bribed to use J\&J products in return for trips. Use of the mails and interstate commerce was also used to facilitate the bribery schemes in Greece and Poland. J\&J's subsidiaries made numerous illicit payments for the purpose of obtaining contract in Iraq, Romania, Greece and Poland. The SEC report notes that:

'J\&J's books and records did not reflect the true nature of those payments. Certain J\&J subsidiaries created false contracts, invoices, and other documents to conceal the true business arrangement it had with its consultants and distributors to bribes. False documents were created, and petty cash was used to pay bribes. United Nations contracts were also falsified'. (p. 18).

$\mathrm{J} \& \mathrm{~J}$ also failed to implement adequate internal controls to detect or prevent bribery. The conduct was widespread in various markets, Greece, Poland, Romania and Iraq. The conduct involved employees and managers of all levels, false documents were routinely created to conceal the bribery in each country (United States District Court for the District of Columbia, 2011). 
It was reported that rather than cease the bribery that was happening at DePuy prior to its acquisition, J\&J through its subsidiaries, employees and agents allowed the bribery to continue. They created sham businesses and entered into contracts that were merely conduits to allow the bribery to flourish. They failed to conduct due diligence on the Greek distributor. MD\&D Poland also entered into fake civil contracts with Polish doctors and $J \& J$ also created false travel arrangements in Poland and Romania to create slush funds. Cilag and Janssen paid bribe to Iraq despite the fact that trade sanctions were in place against doing business in Iraq. Cilag and Janssen falsified their contracts with the United Nations to conceal the kickbacks being paid to Iraq (United States District Court for the District of Columbia, 2011). As a consequence, SEC filed an action against Johnson and Johnson that it violates the FCPA by bribing public doctors in several European countries and paying kickbacks to Iraq to illegally obtained business. SEC alleges that:

'Since at least 1998, subsidiaries of the New Brunswick, N. J.- based pharmaceutical, consumer product, and medical device company paid bribes to public doctors in Greece who selected $J \& J$ surgical implants, public doctors and hospital administrators in Romania to prescribe $J \& J$ pharmaceutical products. $J \& J$ subsidiaries also paid kickbacks to Iraq to obtain 19 contracts under the United Nations Oil for Food program'. (United States District Court for the District of Columbia, 2011, pp. 19-20).

As part of the settlement, J\&J agreed to pay more than $\$ 48.6$ million in disgorgement and prejudgment interest to settle the SEC's charges and to pay a $\$ 21.4$ million fine to the DOJ to settle criminal charges.

\section{Summary and Conclusion}

This paper has sought to stimulate debates about the supply side of corrupt practices in developing countries to illuminate the role played by US Multinational companies. What we have presented here is just a sample of episode of what took place during the last decade. The evidence presented in this paper has shown that bribery undermines the main objective of promoting democratically accountable governments and professional civil services in developing countries and free enterprise system. In pursuit of higher financial rewards, promotions and status, such practices seems to be crafted and sanctioned by highly paid executives or dull the systemic pressure for higher profits and returns.

Corruption has both the demand and supply aspects to it, and the action of the bribepayers are as important as those of bribe-takers in determining the level of corruption in developing countries (Otusanya, 2010, 2011a). As the evidence shows, the corporate sector often portrayed as the victim of corruption, is an important source of endemic corrupt practices in developing countries. The corruption and bribery practices are highly institutionalised as long a business executives are rewarded for increases in profits there may be economic incentives to engage in predatory behaviour. MNC do not seem to have been constrained by any notion of ethics or morality. Repeated fines and warning since the 1970s from regulators did not curb violations of rules (either regulatory or accounting), and anti-social behaviour by MNCs. Despite numerous commissions and inquiries, the ethics of business managers, improper accounting still occurred, and audit firms either could not or did not stop them or even report once discovered. It has been reported that in many cases western companies and western agents have been guilty of 
offering and paying bribes to government officials to secure contracts and other advantages (AAPPG, 2006; Otusanya, 2010, 2011a). While some accountant may be unwittingly caught up in antisocial financial practices, it is relevant to ask how much of this activity cannot easily take place without the active and passive involvement of company accountants. Compin (2008) noted that:

'By creating fake balance-sheet, fictitious entries, fraudulent and fictitious billing networks and ad hoc entities specifically for short-term assignments, accountants and legal advisers are able to resolve the dilemma of ownership rights so that instead of criminals being locked into illegal networks their seemingly healthy social structure allow them to fit into the logic of criminal globalisation'. (p. 596).

These bribery cases only present the tip of an iceberg of FCPA violations committed by MNCs in the course of their worldwide operations. However, it raises some question about the nature of enterprise culture embraced by some MNCs. While complying with the relevant sections of FCPA 1977, MNCs may create a positive image for foreign investors, regulators and governments that they are doing something to improve the quality of financial information reporting, little has changed in actuality. The evidence also point to the potential and limitation of such accounting reform as anti-corruption strategy. Accounting reform measures, such as the internal control and books and records requirement of FCPA may have made some improvements on corporate accounting practices, their enforcement will not automatically bring down the level of bribery by MNCs in developing countries. Despite FCPA and other international initiatives aimed at curbing corruption around the world, level of corruption and bribery has increased and is estimated to be over \$1 trillion each year (AAPPG, 2006, Baker, 2005).

Evidence therefore shows that corporate hand in bribery and corrupt practices is sometime given visibility by regulators. The role of SEC has been consistent in protecting the best interest of all stakeholders. By suing several US corporations for questionable illicit payments, the SEC succeeded in sending a clear message to the corporate community that it intended to restore the efficiency of the system of corporate accountability. For example, the US drug manufacturer J\&J admitted that some of its subsidiaries made improper payments in connection with sales of medical devices in a number of countries.

Anti-social financial practices hinder economic development and reduce investment in infrastructures, institutions and social services, thereby forcing ordinary consumers to pay higher prices and degrading the quality of life of millions of citizens. Such practices also make public contracts more expensive as they increase the cost of doing business. As a consequence, investors are likely to be reluctant to invest in development projects in in developing countries. There is a high level of risk associated with such investment practices, as government revenues disappear into the pockets of corrupt public officials (as shown in the case studies above), while the poor are denied access to education, healthcare, clean water and a decent standard of living. To combat anti-social practices and corruption there is a need to educate company executives, policymakers and the public about the human costs of anti-social and corrupt financial as they deprive ordinary citizens of their human and social rights. 
This study reported that bribery and corruption are widely perpetuated by foreign MNCs operating in developing countries. Moreover, the private sector is often at the centre of bribery and corrupt practices either as enablers or as victims disadvantaged by corruption. Although some have suggested that involving the private sector in the fight against antisocial practices might be helpful, the difficulty is how to reconcile the systemic pressures to increase private profits with social welfare. To this end the developing states may review their Companies Act to compel a corporation to explain and publish in its financial reports that it has paid a bribe under a related party transaction. The accounting standards dealing with related party transactions may need to be strengthened (by compelling MNCs to disclose information about: which entities make up the MNCs; where those entities are located and what they do; what values of sales they make in each states amongst others) in order to promote greater transparency. However, as the standard-setters have been colonised by the local and global economic elite, they are likely to lobby against its inclusion in any reform agendas.

This study has shown that anti-social practice is a global phenomenon which requires both local and global solutions. Although a number of international initiatives ${ }^{14}$ have been established to criminalise the bribery of public officials (to address the supply side of corruption) and to provide mutual legal assistance, considerable problems of compliance and enforcement by member states remain. Thus, there is a need to establish an international adjudication system, possibly within the United Nations, to enable developing countries to seek sanctions against non-compliant countries. This paper therefore argues that global co-operation under the umbrella and auspices of the United Nations should be encouraged.

14 These includes; Federal Corrupt Practices Act 1977, OECD Anti-Bribery Convention 1997; UN Convention Against Corruption 2005, and World Bank Anti-Corruption Strategies. 


\section{References}

AAPPG, (2006) 'The Other Side of the Coin: The UK and Corruption in Africa', A Report by the Africa All Party Parliamentary Group, March, 2006.

Ades, A. and Di Tella R. (1999) 'Rent. Competition and Corruption', American Economic Review, 89 (4): 982-93.

Annual Integrity Report (2005-2006) 'Second Integrity Report covering Fiscal Year 2005-2006’, World Bank Group, February 2007.

Bakan, J. (2004) The Corporation: The Pathological Pursuit of Profit and Power, London: Constable and Robinson Ltd.

Bakre, O. M. (2007) 'The Unethical Practices of Accountants and Auditors and the Compromising Stance of Professional Bodies in the Corporate World Evidence from Corporate Nigeria', Accounting Forum, 31(3): 277-303.

Bakre, O. M. (2011) 'Corporate Governance Practices as a Reflection of the Sociopolitical Environment in Nigeria', International Journal of Critical Accounting, 3 (2/3): 133-170.

Briloff, A. J (1972) Unaccountable Accounting, Harper \& Row, Publishers, New York.

Briloff, A. J (1976) More Debit than Credit, Harper and Row Publisher, New York.

Briloff, A. J. (1981) The Truth About Corporate Accounting, Harper and Row Publishers, New York.

Christian Aid (2006) 'UK Profits From Sub-Saharan Africa Despite Aid and Debt

Pledges" Christian Aid News, Online. Available at: http://www.christianaid.org.uk/news/media/pressrel/060705p.htm (accessed 5 July 2006).

Compin, F. (2008) 'The Role of Accounting in Money Laundering and Money Dirtying', Critical Perspectives on Accounting, 19: 591-602.

Department of Justice (2011) 'Armor Holdings Agrees to pay $\$ 10.2$ million Criminal Penalty to Resolve Violations of the Foreign Corrupt Practices Act', Office of Public Affairs, available at www.justice.gov/criminal/fraud/fcpa accessed on 16 January, 2012.

FCPA (1977) 'Unlawful Corporate Payment Act of 1977,' House of Representatives, Report No. 95-640.

Gillespie, K., and Okruhlik, G. (1991) "The Political Dimensions of Corruption Cleanups: A Framework for Analysis', Comparative Politics, 24 (1): 77-95.

Herlihy, E. D. And Levine, T. A. (1976) 'Corporate Crisis: The Overseas Payment Problem', Law and Policy in International Business, 8: 547. 
Johnson, T. (1972) Professions and Power, Macmillan, London.

Johnston, M. (2005) Syndromes of Corruption: Wealth, Power, and Democracy, Cambridge University Press.

Khan, M. A. (2006) 'Role of Audit in Fighting Corruption', Paper Prepared for Ad Hoc Group Meeting on Ethics, Integrity, and Accountability in the Public Sector: Re-building Public Trust in Government through the Implementation of the UN Convention Against Corruption, St. Petersburg, Russia.

Kimbro, M. B. (2002) 'Cross-country Empirical Investigation of Corruption and its Relationship to Economic, Cultural and Institutional Variables: An Examination of the Role of Accounting and Financial Statements Quality', Journal of Accounting, Auditing and Finance, 17 (4): 325-349.

Latour, B. (1993), We Have Never Been Modern, Prentice, Essex.

Lehman, C. R. (1995) , Markus Wiener Publishers.

Miller (1979) Accounting for Corporate Misconduct Abroad: The Federal Corrupt Practices Act of 1977', Cornell International Journal, 12: 273-307.

Mitchell, A., Sikka, P. and Willmott, H. (1998) 'Sweeping it Under the Carpet: The Role of Accountancy Firms in Money Laundering', Accounting, Organisations and Society, $23(5 / 6): 589-607$.

Neu, D., Rahaman, A., Everett, J. and Akindayomi (2010) The Sign Value of Accounting: IMF Structural Adjustment Programs and African Banking Reform', Critical Perspectives on Accounting, 21 (5): 402-419.

Olurode, 'L. (2005) 'Corruption as a Social Problem', in 'Lai Olurode and Remi Anifowose (eds.) Rich but Poor: Corruption and Good Governance in Nigeria, The Faculty of Social Sciences, 1-18.

Otusanya, O. J. (2010) An Investigation of Tax Evasion, Tax Avoidance and Corruption in Nigeria, Unpublished Doctoral Thesis, University of Essex, United Kingdom.

Otusanya, O. J. (2011a) 'The Role of Multinational Companies in Corrupt Practices: The Case of Nigeria', International Journal of Critical Accounting, 3 (2/3): 171-203.

Otusanya, O. J. (2011b) 'The Role of Professionals in Anti-Social Financial Practices: A Case of Nigeria', Accountancy Business and the Public Interest, 11: 42-93.

Otusanya, O. J. (2011c) 'Corruption as an Obstacle for Development in Developing Countries: A Review of Literature', Journal of Money Laundering Control, 14 (4): 387422. 
Otusanya, O. J., Ajibolade, S. O. and Omolehinwa, E. O. (2012) 'The Role of Financial Intermediaries in Elite Money Laundering Practices: Evidence from Nigeria', Journal of Money Laundering Control, 15 (1): 58-84.

Owolabi, A. (2011) Corruption and Environment of Accounting and Auditing in Africa', International Journal of Critical Accounting, 3 (2/3): 220-234.

Rose-Ackerman, S. (1978) Corruption; A Study in Political Economy, London, Academic Press.

Rose-Ackerman, S. (1996) 'Redesigning the State to Fight Corruption: Public Policy for Private Sector', World Bank Report, 1996.

SEC Litigation Release (2011) 'Securities and Exchange Commission v. Armor Holdings, Inc., Accounting and Auditing Enforcement Release No. 3302, 13 July 2011, available on http://www.sec.gov/litigation/litreleases.2011//r22037.htm accessed on 16 January 2011.

Shaxson, N. (2007) Poisoned Wells: The Dirty Politics of African Oil, New York: Palgrave, Macmillan.

Sikka, P. (2008) 'Enterprise Culture and Accountancy Firms: The New Master of Universe', Accounting, Auditing and Accountability Journal, 21(2): 268-295.

Sikka, P. (2010) 'Smoke and Mirrors: Corporate Social Responsibility and Tax Avoidance', Being Paper Presented at Essex Accounting Centre, Essex Business School, University of Essex, UK.

Tinker, T. (1985) Paper Prophets: Fraudulent Accounting and Failed Audits, Beard Books, Washington D C.

Transparency International (2009) Global Corruption Report 2009: Corruption and Private Sector, Cambridge University Press.

United States District Court for the District of Columbia (2011) US SEC v. Johnson and Johnson, Case: 1:11-cv-00686.

United States District Court for the District of Columbia (2011) US SEC v. Armor Holdings, Inc., Case: 1:11-cv-01271.

US District Court Southern District of Texas (2008), SEC v. Willbros Group Inc., et al., Case 4:08-cv-01494.

US Senate Sub-Committee on Investigations (2003) U.S. Tax Shelter Industry: The Role of Accountants, Lawyers, and Financial Professionals, Online. Available at: 
http://levin.senate.gov/newsroom/supporting/2003/111803TaxShelterReport.df (accessed 28 June 2006).

Vanasco, R. R. (1999) 'The Foreign Corrupt Practices Act: An International Perspective', Managerial Auditing Journal, 14 (4-5): 159-262.

Varese, F. (2000) 'Pervasive Corruption" in A. L Edeneva and M. Kurkchiyan (eds) Economic Crime in Russia, London: Kluwer Law International, 99-111.

Veblen, T. (1904) The Theory of Business Enterprise, New York: C. Scribner's Sons.

World Bank, (1997) Helping Countries Combat Corruption: The Role of World Bank, available on-line at: http://www1.worldbank.org/publicsector/anticorruption/coruption/corrptn.pdf (accessed 31 October 2006).

Wu, Z. (2005) Firm Accounting Practices, Accounting Reforms and Corruption in Asia, Policy and Society, 24 (3): 53-78.

Zakiuddin, A. and Haque, W. (2002) 'Corruption in Bangladesh: An Analytical and Sociological Study', Online. Available at: http://unpan1.un.org/intradoc/groups/public/documents/apcity/unpan004881 (accessed 28 October 2006). 